Article

\title{
Spatial and Temporal Analysis of Organic and Black Carbon Mass Concentrations in Lithuania
}

\section{Julija Pauraitė, Genrik Mordas, Steigvilè Byčenkienė and Vidmantas Ulevicius *}

State Research Institute Center for Physical Sciences and Technology, Savanorių Avenue 231, Vilnius, Lithuania; E-Mails: julija.pauraite@ftmc.lt (J.P.); genrik.mordas@ftmc.lt (G.M.); steigvile.bycenkiene@ftmc.lt (S.B.)

* Author to whom correspondence should be addressed; E-Mail: ulevicv@ktl.mii.lt; Tel.: +370-266-16-44; Fax: +370-5-260-23-17.

Academic Editor: Robert W. Talbot

Received: 3 July 2015 / Accepted: 5 August 2015 / Published: 19 August 2015

\begin{abstract}
Both organic carbon (OC) and black carbon (BC) mass concentrations were measured in Lithuania at coastal/marine (Preila), rural (Rūgšteliškis), and urban background (Vilnius) environments have been analyzed to infer the spatial and temporal distributions of the OC/BC ratios from May 2013 to October 2014. OC/BC ratios reflected the location of the different sites, as well as possible different sources influencing air quality. The results from an industrialized and populated urban background area indicated that biomass combustion for heating contributed to BC and OC mass concentration. Typically, BC mean concentrations ( \pm st.deviation) were higher in urban areas $\left(1.72\left( \pm 1.22 \mu \mathrm{g} \cdot \mathrm{m}^{-3}\right)\right)$ than in rural $\left(0.40\left( \pm 0.35 \mu \mathrm{g} \cdot \mathrm{m}^{-3}\right)\right)$ and coastal/marine $\left(0.53\left( \pm 0.43 \mu \mathrm{g} \cdot \mathrm{m}^{-3}\right)\right)$ during warm and cold (2.34( \pm 2.15$) ; 0.77( \pm 0.52)$ and $0.84( \pm 0.50) \mu \mathrm{g} \cdot \mathrm{m}^{-3}$, respectively) periods, while OC concentrations were higher in urban backgrounds $\left(5.91\left( \pm 1.99 \mu \mathrm{g} \cdot \mathrm{m}^{-3}\right)\right)$ and rural areas $\left(4.56\left( \pm 3.98 \mu \mathrm{g} \cdot \mathrm{m}^{-3}\right)\right)$ during warm periods. The air mass backward trajectory analysis indicated influence of local sources in urban environment and strong influence of long-range transport in rural environment. A clear seasonal dependence of $\mathrm{OC} / \mathrm{BC}$ ratios was observed at rural and urban environments. The highest $\mathrm{OC} / \mathrm{BC}$ ratios were calculated in coastal/marine (6.3) and rural (9.5) environments in summer.
\end{abstract}

Keywords: aerosol; black carbon; organic carbon; rural; urban 


\section{Introduction}

Atmospheric carbonaceous aerosols constitute a significant part of the atmospheric aerosols, while a large part of them consists of organic material ( $50 \%)$ [1]. The carbonaceous atmospheric particulate matter consists of black carbon (otherwise called elemental carbon (EC) and a variety of organic compounds. Black carbon (BC) is a primary incomplete combustion-generated carbonaceous aerosol with a graphitic-like structure, while organic carbon (OC) may have both primary and secondary origins [2]. Primary OC may result from fossil fuel emissions, biomass burning or represent biological particles or plant debris [3] while the secondary OC can be formed in the atmosphere by gas-to-particle conversion [4]. There are several indirect approaches used to estimate the amount of primary and secondary OC. Among these, OC/EC ratios exceeding values of 2.0 have been used to identify the presence of secondary organic aerosols [5]. Secondary organic aerosols are also associated with high levels of water-soluble organic carbon, induced by photochemical reactions, especially during warm seasons [6]. It is known that OC exhibits a wider size distribution, whereas EC is found generally in the submicrometer range [3]. As BC and $\mathrm{EC}$ in airborne particulate matter originates from the incomplete combustion of carbonaceous fuel [7-8], these two carbonaceous species are often well correlated [9]. A number of studies have been published regarding BC measurements with a view to assess the spatial and temporal variation [10-16] via multiple ground-based instrumentation and techniques. Many research studies have been performed and reported for influence of traffic [17] and domestic biomass burning [18] which play significant roles in the atmosphere of urban areas. The lifetime of BC is about seven days in the troposphere [19] and hence can be transported to long-distances [20]. Thus, it is important that investigations on BC concentrations would be carried out in different environments in order to understand their impacts. Increasing attention was being concentrated in the estimation of primary and secondary OC concentrations [2,3,21-23]. Pio et al. [3] suggested that the ratio of OC and EC could be used as a tool to derive $\mathrm{OC}$ from primary and secondary sources. Although many uncertainties remain with $\mathrm{BC}$ analysis techniques, EC has mostly been used as surrogate for BC [24]. Inter comparison measurements of BC and $\mathrm{EC}$ have been conducted in different countries and environments [25] and substantial differences must be expected. However, the sources of OC still cannot be estimated accurately. In Lithuania, few studies have been carried out on BC measurements with a view to assess their pollution events and annual variation of $\mathrm{BC}$ mass concentration [26,27]. There have not been previous long-term OC measurements.

The aim of this study is to characterize the variations of $\mathrm{BC}$ and $\mathrm{OC}$ aerosols in distinct environments of Lithuania. We have performed seasonal variations of $\mathrm{BC}$ and $\mathrm{OC}$ to show spatial and temporal alteration and determine important sources at each environment. The long-range transport of $\mathrm{BC}$ between two sites and analysis of $\mathrm{OC} / \mathrm{BC}$ ratios also has been presented. This study can improve the understanding of the carbonaceous aerosol sources in Baltic region.

\section{Methods}

\subsection{Measurement Sites Description}

The continuous measurements of the mass concentrations of $\mathrm{BC}$ and $\mathrm{OC}$ were performed at three different sites in different seasons (Figure 1). The study sites were selected in different geographical positions in order to have a wide range of the levels of BC and $\mathrm{OC}$ in Lithuania. Ambient levels of BC 
and OC were studied at a Preila (March-April 2014), Rūgšteliškis (November 2013, May 2014) and Vilnius (December 2013, October 2014). The main difference between the sites is the amount of seasonal fluctuation in $\mathrm{BC}$ and $\mathrm{OC}$ levels observed each year. Environmental pollution research site Preila $\left(55^{\circ} 55^{\prime} \mathrm{N}, 21^{\circ} 00^{\prime} \mathrm{E}, 5 \mathrm{~m}\right.$ above the sea level (a.s.1.)) is located in the coastal/marine environment on the Curonian Spit, between Curonian Lagoon and the Baltic Sea. A road along the spit connects summer resorts and fishing villages. At Curonian Spit's north end, lagoon is connected to the Baltic Sea by the Lithuanian port of Klaipeda-the nearest industrial city at a distance of about $40 \mathrm{~km}$ to the north from Preila. The other major city Kaliningrad (Russia) is about $90 \mathrm{~km}$ to the south. Preila site is characterized as a regionally representative background area characterized by tender winter, middling summer and rapidly changing meteorological conditions. Rūgšteliškis integrated monitoring site $\left(55^{\circ} 46^{\prime} \mathrm{N}, 26^{\circ} 00^{\prime} \mathrm{E}\right.$, $160 \mathrm{~m}$ above Sea level, rural forested environment) is located at a distance of about $313 \mathrm{~km}$ east from Preila-in Aukštaitija. This site is located in the north-eastern part of Lithuania, in remote forested (forests cover $70 \%$ of park's area, mostly 60 years old in average pine (Pinus sylvestris) stands and sparsely populated area with vegetation varied from steppe to tundra species. The measurements were taken at $1.5 \mathrm{~m}$ above the ground level. The climate can be described as middling cold with higher humidity and considerable rainfall. The nearest major city Utena is about $27 \mathrm{~km}$ to the south from Rūgšteliškis.

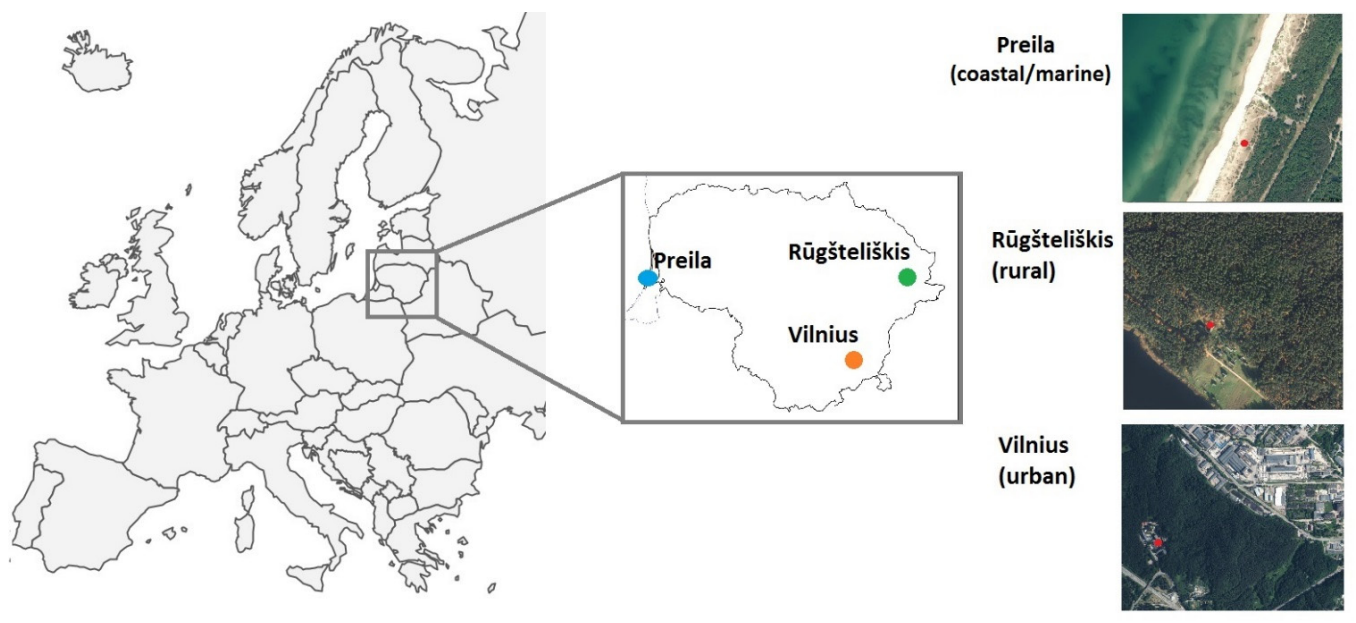

Figure 1. Map of Lithuania and the sampling locations.

Vilnius sampling site $\left(54^{\circ} 64^{\prime} \mathrm{N}, 25^{\circ} 18^{\prime} \mathrm{E}, 112 \mathrm{~m}\right.$ above Sea level is located at the center for physical science and technology campus. The continuous BC and OC measurements were taken about $20 \mathrm{~m}$ above the ground level, $12 \mathrm{~km}$ southwest of city center area. Vilnius is the largest city and the capital of Lithuania, with a population of 0.5 million. The main local anthropogenic particle source is traffic and heating-generated pollution during cold season (October-April). The location can be described as an urban background. Pollution emitted from the city can be easily transported to the site with the prevailing northeast wind. Vilnius is at a distance of about $280 \mathrm{~km}$ south-east from Preila and $105 \mathrm{~km}$ south from Rūgšteliškis.

\subsection{Instrumentation}

The Magee Scientific Company aethalometer (Model AE31 Spectrum manufactured by Aerosol d.o.o., Slovenia) was deployed at the Preila, Rūgšteliškis and Vilnius sites for the real-time measurements of 
BC mass concentration. The sampling aerosol flow of aethalometer of $41 /$ min passed through impactor of PM2.5 and vertical $2.5 \mathrm{~m}$ long stainless steel tube (10 mm inner diameter). Measured light attenuation was converted to $\mathrm{BC}$ mass. The optical transmission of carbonaceous aerosol particles was measured sequentially at seven wavelengths $\lambda(0.37,0.45,0.52,0.59,0.66,0.88$ and $0.95 \mu \mathrm{m})$. At $0.88 \mu \mathrm{m}$ wavelength, $\mathrm{BC}$ is the principal absorber of light and other aerosol components have a minor influence for absorption. Because of this characteristic $0.88 \mu \mathrm{m}$ wavelength was considered as representing channel of $\mathrm{BC}$ measurements in the atmosphere. $\mathrm{BC}$ aerosol mass concentration was measured with 5 min resolution. An empirical algorithm for loading effects compensation was used [28,29].

The chemical composition of non-refractory submicron particulate matter was measured using the Aerosol Chemical Speciation Monitor (ACSM) (Aerodyne Research, Inc., Billerica, MA, USA). Before reaching the instrument, the sampling aerosol flow of $1.6 \mathrm{lpm}$ passed through a PM10 impactor-inlet (self-design), a $2.5 \mathrm{~m}$ vertical stainless steel sampling tube (6 $\mathrm{mm}$ inner diameter) and a Nafion dryer (MD-110-48S-4, Perma Pure LLC, Toms River, NJ, USA). The impactor removed coarse particles, while a flowrate of $1.6 \mathrm{l} / \mathrm{min}$ minimized the particle transport losses in the particle size range from $30 \mathrm{~nm}$ to $1 \mu \mathrm{m}$ and the dryer set the relative humidity lower than $50 \%$. Particle losses in the line were estimated to be lower than $2 \%$. Reaching ACSM, the submicron aerosol particles were focused into a resistively heated surface at $600{ }^{\circ} \mathrm{C}$, where the non-refractory $\mathrm{PM}_{1}$ components were flash vaporized. The resulting gases were subsequently detected and chemically characterized with $70 \mathrm{eV}$ electron impact quadrupole mass spectrometry. The instrument was operated with a time resolution of $30 \mathrm{~min}$ for typical aerosol loadings (several $\mu \mathrm{g} \cdot \mathrm{m}^{-3}$ ) with a scan rate of mass spectrometer at $220 \mathrm{~ms} \cdot \mathrm{amu}^{-1}$ from $\mathrm{m} / \mathrm{z} 10$ to 140 (approximately $31.9 \mathrm{~s}$ per scan and $1.126 \mathrm{~s}$ pause, 56 scans and data interval $29 \mathrm{~min} 48 \mathrm{~s}$ ). The mass concentrations and mass spectra were processed using ACSM standard data analysis software (v 1.5.3.0) and DAQ 1.4.4.4. Under ambient conditions, the mass concentration of organic matter (OM), sulphates $\left(\mathrm{SO}^{2-}{ }_{4}\right)$, nitrates $\left(\mathrm{NO}^{-3}\right)$, ammonium $\left(\mathrm{NH}^{+}{ }_{4}\right)$ and chlorides $\left(\mathrm{Cl}^{-}\right)$were measured with a detection limit $<0.2 \mu \mathrm{g} \cdot \mathrm{m}^{-3}$. The instrument was periodically main tenanced and calibrated using ammonium sulphate and ammonium nitrate. Experimentally determined calibration parameters were response factor RFNO3 and relative ionization efficiencies RIENH4, RIESO4. The relative ionization efficiencies RIEOrg = 1.4, RIEChl $=1.3$ were set as the default. A collection efficiency (CE) was calculated from the measurement data using collection efficiency calculation algorithm suggested by Middlebrook et al. [28]. The instrument was calibrated using ammonium sulphate and ammonium nitrate. A collection efficiency (CE) was calculated using collection efficiency calculation algorithm suggested by Middlebrook et al. [28]. The average values of CE in Preila, Rūgšteliškis and Vilnius during cold period were 0.87, 0.74 and 0.70, respectively. While during warm period the average values of $\mathrm{CE}$ were $0.84,0.88$ and 0.50 , respectively. The OC concentration was calculated from ratio of organic-mass-to-organic-carbon convert was done by Russel taken mean value of 1.4 which is typically taken to be 1.4 [30]. Thus, both BC and EC are generated from anthropogenic sources and was used to describe aspects of ambient particulate matter. In order to systematize ratio of carbonaceous aerosol concentrations, the comparison with other sites were made. The estimations of $\mathrm{OC} / \mathrm{BC}$ and $\mathrm{OC} / \mathrm{EC}$ ratios were made to compare values of parameter $\alpha$. In this study, parameter $\alpha$ was determined by coefficient of linear fitting curve. To simplify the analysis, parameter $\alpha$ can be also evaluated by, 


$$
\alpha=\frac{180^{\circ}}{\pi} \cdot \tan ^{-1} \frac{\mathrm{OC}}{\mathrm{BC}}
$$

where $\mathrm{OC} / \mathrm{BC}$ represents averaged ratio of carbonaceous aerosols concentrations for investigation period.

The sampling time in all stations was considered in a way to represent both warm and cold periods.

\subsection{Air Mass Backward Trajectories}

The air mass backward trajectory analysis provides knowledge about long-range transport patterns [30]. The aerosol characteristics with respect to air masses advection to estimate the transfer of aerosol particles between stations were analyzed. The trajectories were calculated for the days when air masses clearly pass through whole country territory from Baltic Sea towards continent. However, it is not possible to quantitatively separate the increment of transported aerosol concentration from that locally emitted. Therefore, studies in marine, rural and urban background area will be required to quantify the extent of transported material during the study periods. Additionally, 72-hour backward trajectories were computed using the HYbrid Single-Particle Lagrangian Integrated Trajectory (HYSPLIT) model [31] with the Global Data Assimilation System (GDAS) meteorological databases at the NOAA Air Resources Laboratory's web server (http://ready.arl.noaa.gov/HYSPLIT_traj.php) for each measurement site with starting height of $500 \mathrm{~m}$ above sea level.

\section{Results and Discussion}

\subsection{Seasonal and Diurnal Variations}

Statistics of BC and OC concentrations measured from May 2013 to October 2014 in the coastal/marine, rural and urban background environments are summarized in Table 1. BC and OC concentrations show large variations with means ( \pm standard deviation) of $0.98( \pm 0.81)$ and $4.86( \pm 4.31) \mu \mathrm{g} \cdot \mathrm{m}^{-3}$, respectively, for the entire observation period. For analysis the annual data of $\mathrm{BC}$ and $\mathrm{OC}$ mass concentrations were divided into cold and warm periods. The hourly mean data show that atmospheric BC loading was higher during cold periods in all three environments. The highest hourly $\mathrm{BC}$ aerosol mass concentration in Vilnius reached $17.23 \mu \mathrm{g} \cdot \mathrm{m}^{-3}$ during cold period, while the mean BC concentration was found to be $2.34 \mu \mathrm{g} \cdot \mathrm{m}^{-3}$, which is about a factor of three higher than mean values in Preila and Rūgšteliškis sites (0.84 and $0.77 \mu \mathrm{g} \cdot \mathrm{m}^{-3}$, respectively) (Table 1$)$. The lowest hourly $\mathrm{BC}$ aerosol mass concentration of $0.02 \mu \mathrm{g} \cdot \mathrm{m}^{-3}$ was observed in Preila during both warm and cold periods. Meanwhile, the mean BC aerosol mass concentration in Rūgšteliškis was lower by a factor of two during warm period $\left(0.40 \mu \mathrm{g} \cdot \mathrm{m}^{-3}\right)$ compared to cold period $\left(0.77 \mu \mathrm{g} \cdot \mathrm{m}^{-3}\right)$. The highest mean BC mass aerosol concentration during warm period was observed in Vilnius $\left(1.72 \mu \mathrm{g} \cdot \mathrm{m}^{-3}\right)$, which is about a factor of 4.3 and 3.2 higher than those measured in Rūgšteliškis $\left(0.40 \mu \mathrm{g} \cdot \mathrm{m}^{-3}\right)$ and Preila $\left(0.53 \mu \mathrm{g} \cdot \mathrm{m}^{-3}\right)$, respectively. As can be seen, the differences in ambient BC levels may be caused by different sampling location and season as well as different emission sources. It was concluded that annual mean BC aerosol mass concentrations in Vilnius were significantly higher than those measured at coastal/marine and rural environments as domestic biofuel use, transportation and industry sectors are important emission sources in Vilnius [26]. 
Table 1. The concentrations $\left(\mu \mathrm{g} \cdot \mathrm{m}^{-3}\right)$ of black carbon $(\mathrm{BC})$ and organic carbon $(\mathrm{OC})$ during warm and cold periods at the rural (Rūgšteliškis), coastal/marine (Preila) and background urban (Vilnius) environments.

\begin{tabular}{ccccccccccccccc}
\hline Location & \multicolumn{4}{c}{ Rugšteliškis } & \multicolumn{4}{c}{ Preila } & \multicolumn{4}{c}{ Vilnius } \\
\hline & \multicolumn{3}{c}{ BC } & \multicolumn{3}{c}{ OC } & \multicolumn{3}{c}{ BC } & \multicolumn{3}{c}{ OC } & \multicolumn{3}{c}{ BC } & \multicolumn{3}{c}{ OC } \\
Period & warm & cold & warm & cold & warm & cold & warm & cold & warm & cold & warm & cold \\
mean & 0.40 & 0.77 & 4.56 & 3.45 & 0.53 & 0.84 & 4.11 & 3.01 & 1.72 & 2.34 & 5.91 & 8.60 \\
st. deviation & 0.35 & 0.52 & 3.98 & 2.28 & 0.43 & 1.22 & 3.86 & 2.56 & 1.22 & 2.15 & 1.99 & 7.04 \\
$\min$ & 0.07 & 0.03 & 0.18 & 0.06 & 0.02 & 0.02 & 0.02 & 0.01 & 0.21 & 0.06 & 0.78 & 0.15 \\
$\max$ & 3.79 & 3.05 & 26.79 & 17.28 & 2.23 & 13.60 & 21.71 & 52.72 & 6.84 & 17.23 & 17.78 & 75.44 \\
\hline
\end{tabular}
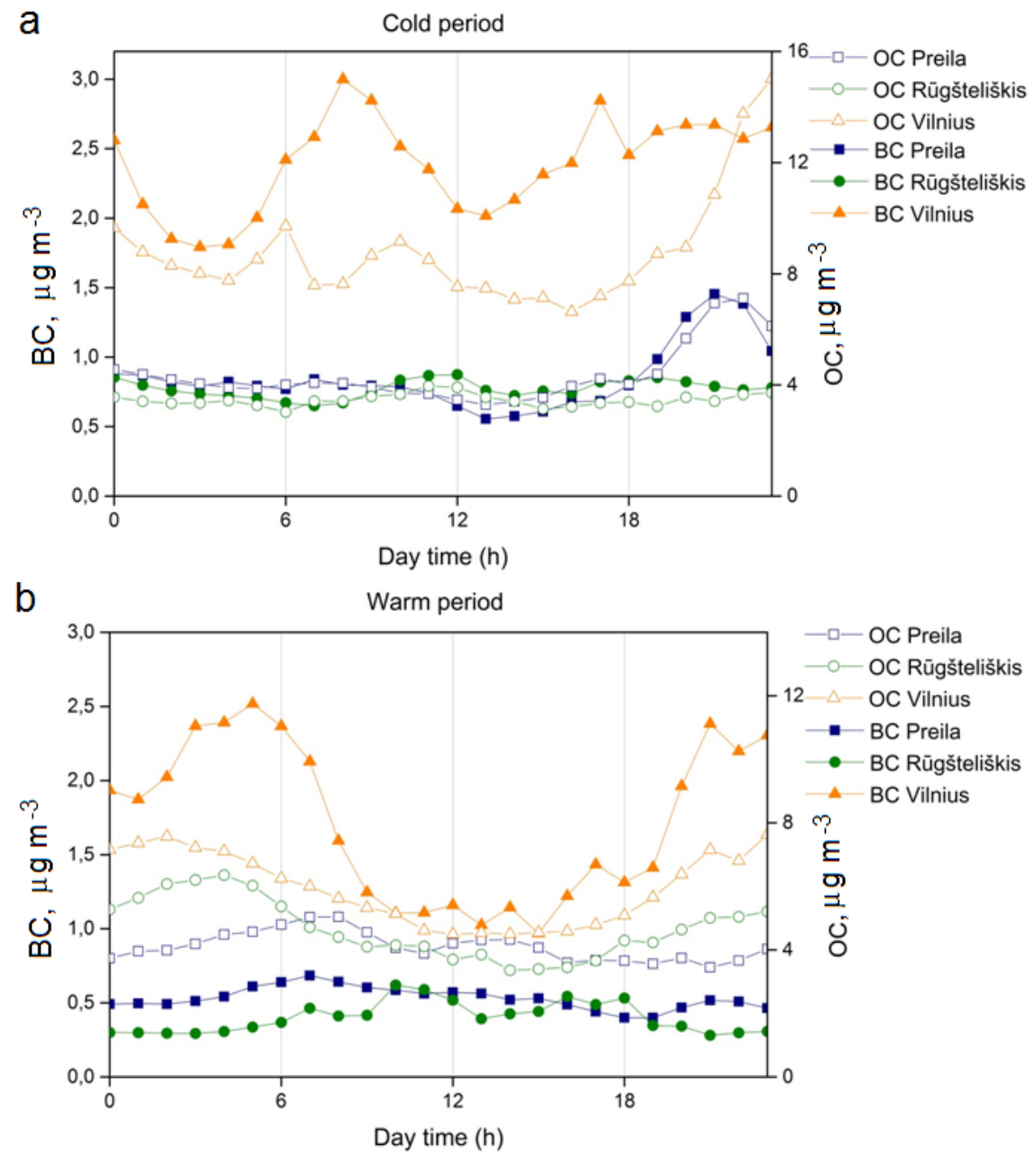

Figure 2. Mean diurnal variation of $\mathrm{OC}$ and $\mathrm{BC}$ mass concentrations during (a) cold and (b) warm periods in the rural (Rūgšteliškis), coastal/marine (Preila) and urban background (Vilnius) environments.

The mean OC concentrations have distinct seasonal variations with the highest values observed $\left(8.60 \pm 7.04 \mu \mathrm{g} \cdot \mathrm{m}^{-3}\right)$ in urban background and lowest mean concentration $\left(3.01 \pm 2.56 \mu \mathrm{g} \cdot \mathrm{m}^{-3}\right)$ in coastal/marine environment in cold period. The minimum OC concentrations moderately varied between $0.01 \mu \mathrm{g} \cdot \mathrm{m}^{-3}$ and $0.78 \mu \mathrm{g} \cdot \mathrm{m}^{-3}$, while the maximum values during cold period $\left(75.44 \mu \mathrm{g} \cdot \mathrm{m}^{-3}\right)$ were more 
than four times higher of those in warm period $\left(17.78 \mu \mathrm{g} \cdot \mathrm{m}^{-3}\right)$ in urban background environment [32]. In rural area contrary situation was observed. The mean OC values measured during the warm period in Preila $\left(4.11 \mu \mathrm{g} \cdot \mathrm{m}^{-3}\right)$ and Rūgšteliškis $\left(4.56 \mu \mathrm{g} \cdot \mathrm{m}^{-3}\right)$ was higher compared to the cold period (3.01 and $3.45 \mu \mathrm{g} \cdot \mathrm{m}^{-3}$, respectively).

The mean diurnal BC and OC mass concentrations are shown in Figure 2. On a daily basis, there was a gradual increase in $\mathrm{BC}$ mass concentrations starting from 05:00 a.m., and the morning peak typically occurred at 08:00 a.m. during cold season (Figure 2a), while the BC mass concentrations were found to be the smallest during day (10:00 a.m.-19:00 p.m.) in the warm season (Figure 2b) in the urban environment due to stronger turbulent mixing and increased mixing layer height resulting in a dilution of $\mathrm{BC}$ mass concentrations [18]. Meanwhile, the OC concentration in Vilnius raised at nighttime that could be explained by domestic heating. The surface inversion after sunset resulted in the accumulation of $\mathrm{BC}$ and $\mathrm{OC}$ emissions, causing higher $\mathrm{BC}$ level in the late evening.

The evening sharp peak of BC and OC values observed between 20:00 p.m. and 20:00 a.m. in coastal/marine site resulting from biomass burning for heating during cold season (Figure $2 \mathrm{a}$ ). $\mathrm{BC}$ and OC concentrations in Preila and Rūgšteliškis sites had no significant daytime peaks during both cold and warm periods. The $\mathrm{BC}$ concentrations during the warm period in rural and marine environments stayed unchanged (Figure 2b).

\subsection{Case Studies: Impact of Long-Range Transport}

In order to investigate the contribution of long-range transport and local sources to the $\mathrm{BC}$ concentrations, the additional air mass backward trajectory analysis was performed. Air mass backward trajectories were used to estimate spatial variation and transfer of $\mathrm{BC}$ and $\mathrm{OC}$ concentrations between investigation sites. Days in which same air masses advected between two sampling sites were chosen as event days. In our study, two of the most representative types of the BC and OC concentrations transfer events between investigation sites in terms of their behavior were investigated. During both of the events, advection of clean air masses, which were transported through the Baltic Sea to the Preila site, were observed. The time shift of air mass passing between two sites was calculated from data of the air mass backward trajectory.

During the first event, the air masses were advected in six hours from Preila towards Vilnius from 20 to 24 of March 2014 (Figure 3a). In 93\% of the event duration, the concentration in Vilnius was higher than in Preila with correlation coefficient of 0.4. The increases of $\mathrm{BC}$ concentration in Vilnius were observed during daytime. Meanwhile, concentrations of $\mathrm{BC}$ during the nighttime were comparable with concentrations in Preila. The distinction of $\mathrm{BC}$ concentrations in Vilnius and Preila has ranged between -0.3 and $4.6 \mu \mathrm{g} \cdot \mathrm{m}^{-3}$ (Figure 3), which could be explained by the significant influence of local sources in the urban environment.

The air mass advected from Preila toward Rūgšteliškis on 13-17 November 2013. The passing time between sites was the same as at the first event, thus the data of BC in Rūgšteliškis was also shifted backward for six hours (Figure $3 \mathrm{~b}$ ). The value of correlation coefficient was 0.7 . In $58 \%$ of event duration the concentration of $\mathrm{BC}$ in Rūgšteliškis was higher than in Preila. The distinction of $\mathrm{BC}$ concentrations ranged from -0.7 and $1.3 \mu \mathrm{g} \cdot \mathrm{m}^{-3}$ with mean $\mathrm{BC}$ concentrations distinction of $0.1 \mu \mathrm{g} \cdot \mathrm{m}^{-3}$. This leads to 
the conclusion that between these two sites there is no significant $\mathrm{BC}$ emission sources. That means that the main contributing source for $\mathrm{BC}$ concentration in rural environments is long-range transport.

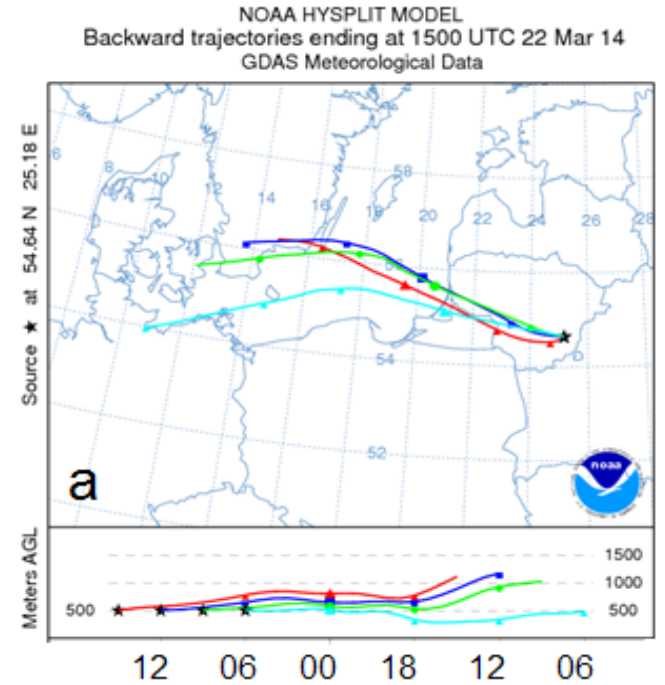

C

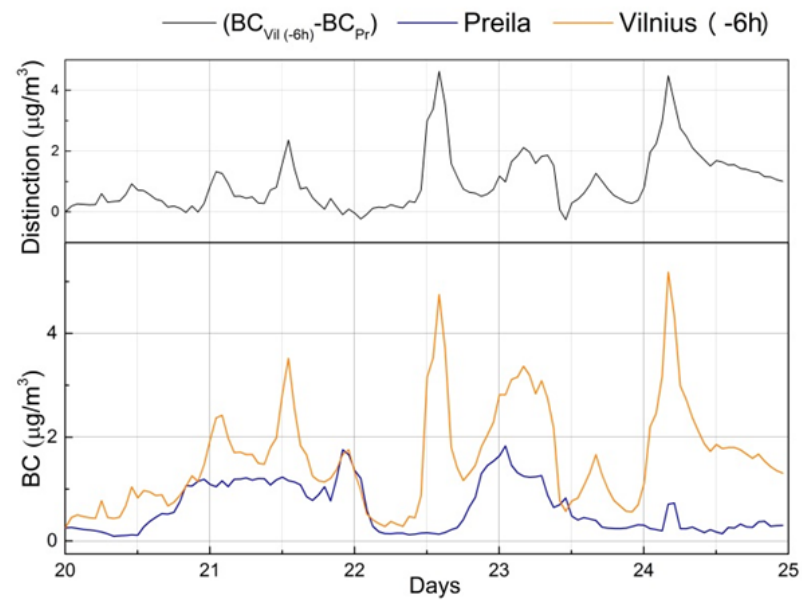

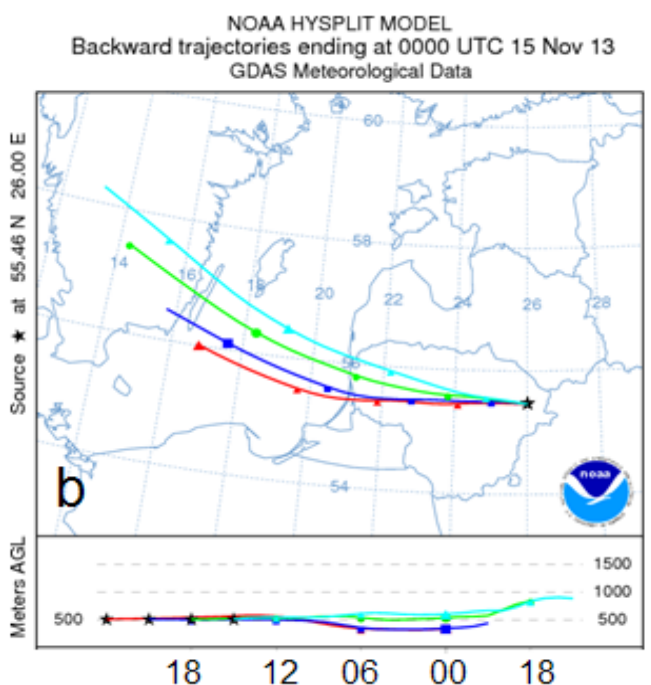

d

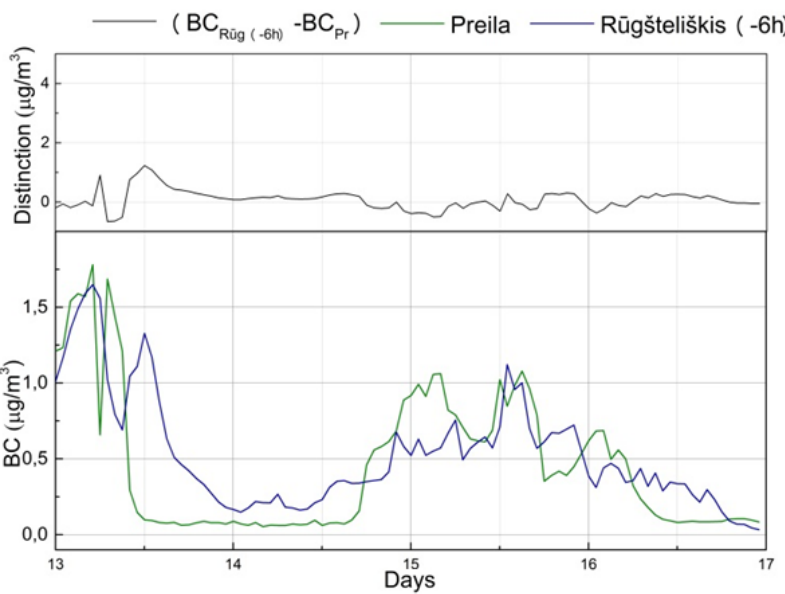

Figure 3. Air mass backward trajectories on (a) 22 March 2014 and (b) 15 November 2013. Time series of black carbon mass concentration in Vilnius and Preila during (c) 20-24 March 2014 and in Rūgšteliškis and Preila during (d) 13-17 November 2013.

\subsection{Correlation between $O C$ and $B C$}

The relation of $\mathrm{BC}$ to $\mathrm{OC}$ showed a moderate positive correlation during cold $(r=0.65)$ and warm $(r=0.43)$ periods in Vilnius, suggesting that there were several sources with different OC/BC ratios that varied in time. Meanwhile, moderate correlation in rural environment indicates other sources, i.e., biogenic OC. Clearly higher correlation coefficients were detected at the marine environment during cold $(r=0.93)$ and warm $(r=0.85)$ periods. Moderate statistical linear relationship in rural environment were found to be $r=0.63$ and $r=0.43$ during cold and warm periods, respectively. This tendency is likely due to the significant influence of air mass long-range transport and domestic biomass burning to both $\mathrm{OC}$ and $\mathrm{BC}$ mass concentrations. The scatter plots of $\mathrm{OC}$ and $\mathrm{BC}$ distribution for three sites are given in Figure 4. 

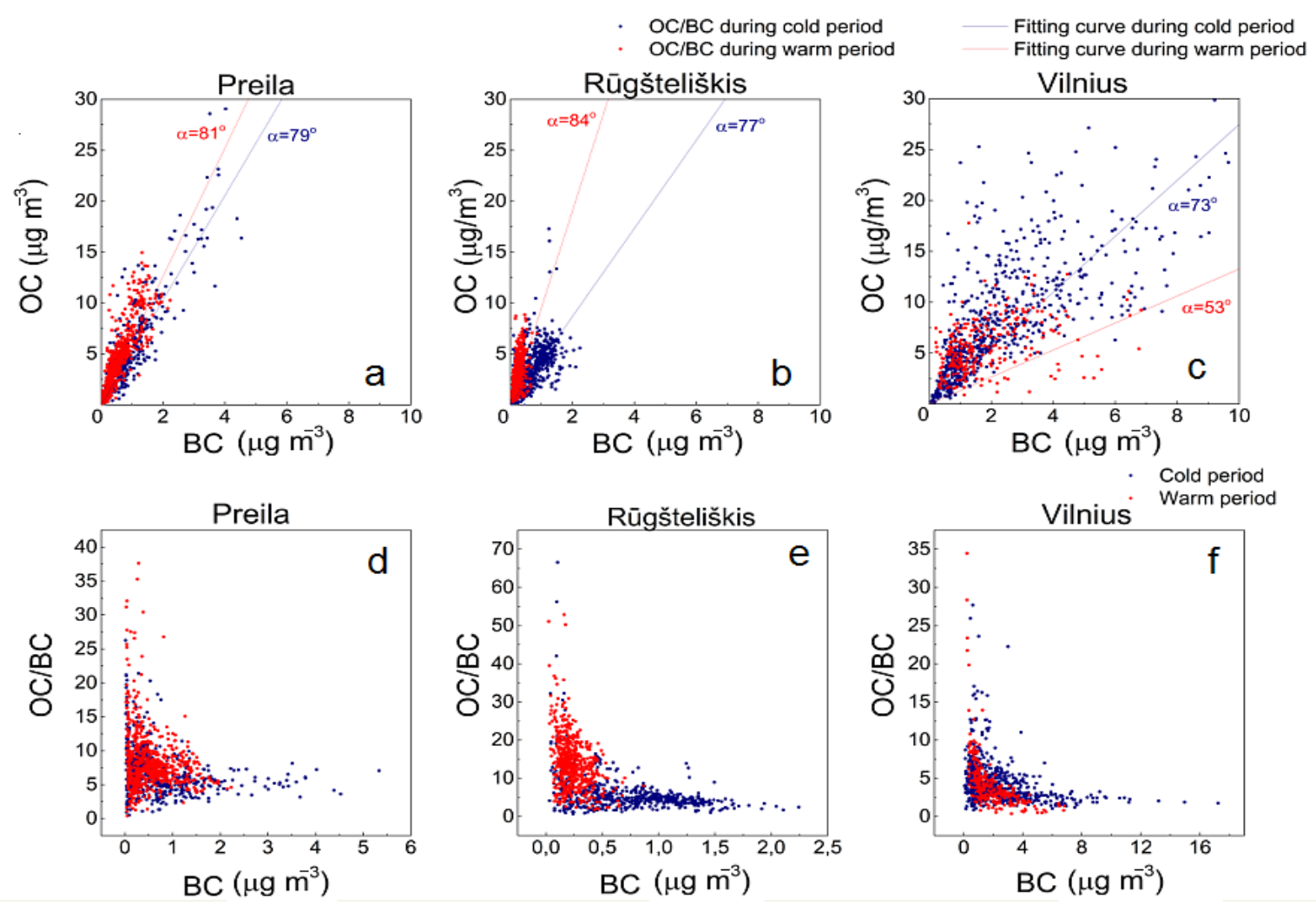

Figure 4. Scatter plots of $\mathrm{OC}$ versus $\mathrm{BC}$ and $\mathrm{OC} / \mathrm{BC}$ versus $\mathrm{BC}$ in $(\mathbf{a}, \mathbf{d})$ coastal $/ \mathrm{marine}$ (Preila), (b,e) rural (Rūgšteliškis) and (c,f) urban background (Vilnius) environments during cold (blue) and warm (red) periods.

The angle $\alpha$ of OC vs. BC fitting curve in Preila were found to be $\alpha=81^{\circ}$ and $\alpha=79^{\circ}$ during cold and warm periods, respectively. This insensitivity to seasonal variations indicates strong influence of air mass long-range transport and no noticeable local source. Similar angle $\left(\alpha=77^{\circ}\right)$ was observed in Rūgšteliškis during the cold period. This alteration of $\mathrm{OC} / \mathrm{BC}$ ratio in Rūgšteliškis could be determined by strong influence of the secondary organic carbon provides a significant contribution to the total OC during the warm period. In contrast to Rūgšteliškis, the ratio of $\mathrm{OC} / \mathrm{BC}$ in Vilnius had the opposite seasonal trend, when the estimated $\alpha$ was significantly higher during cold period $\left(\alpha=73^{\circ}\right.$ and $\alpha=53^{\circ}$, respectively). Urban environment has significant local sources of both organic and black carbon during the cold period; consequently, the value of $\alpha$ in Vilnius is lower than values of $\alpha$ observed in Preila and Rūgšteliškis during cold period. A scatter plot of OC/BC versus BC (Figure $4 \mathrm{~d}-\mathrm{f}$ ) categorized according to season (Figure $4 \mathrm{~d}-\mathrm{f}$ ) shows good separation of data for the highest and lowest BC values. A scatter plot shows that high ratios are clustered at $\mathrm{BC}$ concentrations $<1 \mu \mathrm{g} \cdot \mathrm{m}^{-3}$.Coastal/marine data analysis show similar features with other European studies: extremely high ratios (up to $\sim 30$ ) for $\mathrm{BC}<1 \mu \mathrm{g} \cdot \mathrm{m}^{-3}$ at "background" locations in Italy, Hungary, and Sweden [33]. Seasonally, the lower OC/BC ratio in cold period was owing to biomass burning for heating (Figure $4 \mathrm{~d}-\mathrm{f}$ ).

The high values of $\mathrm{OC} / \mathrm{BC}$ ratio in forested area (Rūgšteliškis) suggest that $\mathrm{OC}$ emissions may be derived from biogenic sources, for which the $\mathrm{OC} / \mathrm{BC}$ ratios are known to be high. The higher OC mass concentration and weak correlation of $\mathrm{OC}$ with $\mathrm{BC}(r=0.43)$ suggest that gas to particle conversion produces substantial amounts of secondary OC in the warmer months. The values of $\alpha$ has been compared with values of parameter $\alpha$ from different sites (Table 2). 
Table 2. Values of parameter $\alpha$ at the various sampling sites in Europe.

\begin{tabular}{|c|c|c|c|c|c|c|}
\hline \multirow{2}{*}{ Station type } & \multirow{2}{*}{ Site } & \multicolumn{2}{|c|}{ OC/BC (or OC/EC) } & \multicolumn{2}{|c|}{$\begin{array}{c}\text { Calculated } \alpha \text { in this } \\
\text { study }\end{array}$} & \multirow{2}{*}{ Reference } \\
\hline & & $\begin{array}{l}\text { Warm } \\
\text { period }\end{array}$ & $\begin{array}{l}\text { Cold } \\
\text { period }\end{array}$ & $\begin{array}{l}\text { Wam } \\
\text { period }\end{array}$ & $\begin{array}{c}\text { Cold } \\
\text { period }\end{array}$ & \\
\hline \multirow{5}{*}{ Urban } & Vilnius & 1.3 & 3.3 & $53^{\circ}$ & $73^{\circ}$ & (This study) \\
\hline & Birmingham & 2.1 & & $65^{\circ}$ & & [3] \\
\hline & Helsinki & $1.7 *$ & $2.2 *$ & $59^{\circ}$ & $66^{\circ}$ & [32] \\
\hline & Lisbon & & 3.1 & & $72^{\circ}$ & {$[3]$} \\
\hline & Oporto & 2.0 & & $63^{\circ}$ & & {$[3]$} \\
\hline \multirow{3}{*}{ Rural } & Rūgšteliškis & 9.5 & 4.3 & $84^{\circ}$ & $77^{\circ}$ & (This study) \\
\hline & Hyytiälä & $9.1 *$ & $5.2 *$ & $84^{\circ}$ & $79^{\circ}$ & [32] \\
\hline & Lamas de Olo & 11.8 & & $85^{\circ}$ & & [3] \\
\hline \multirow{3}{*}{ Coastal/marine } & Preila & 6.3 & 5.1 & $81^{\circ}$ & $79^{\circ}$ & (This study) \\
\hline & Areão & 7.3 & 4.0 & $82^{\circ}$ & $76^{\circ}$ & [34] \\
\hline & Mace Head & 10.8 & & $85^{\circ}$ & & [34] \\
\hline
\end{tabular}

Note: * Recalculated from EC.

As expected, the ratio of $\mathrm{OC} / \mathrm{BC}$ was highest in rural and coastal/marine sites. The carbonaceous aerosol shows a relative enrichment in OC during warm period in these sites $\left(\alpha=84^{\circ}-85^{\circ}\right)$. Meanwhile, ratio of carbonaceous aerosol concentrations in urban sites was lower. The most similar to value of parameter $\alpha$ in Vilnius during warm period was measured in Helsinki (53 ${ }^{\circ}$ and $59^{\circ}$, respectively). In addition, these sites are similar in regards of seasonal behavior [35]. OC/BC ratio in Europe has a mean of $2.69 \pm 0.91$ for urban locations, increasing to values as high as 25 for background locations in Hungary, Italy, and Sweden, where BC concentrations are lower.

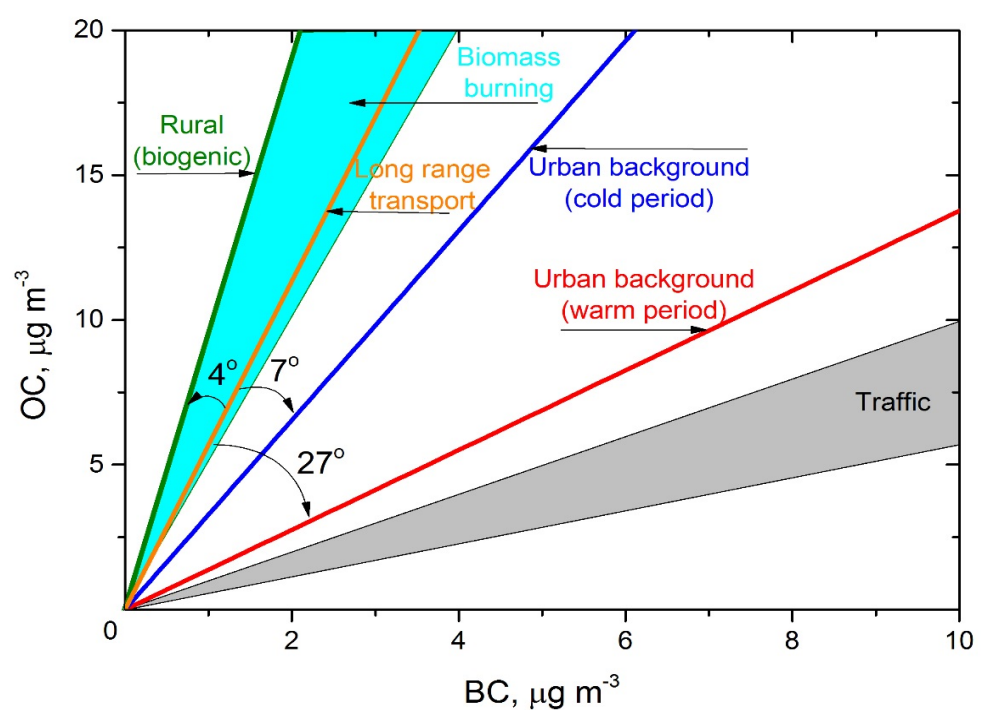

Figure 5. Alteration of parameter $\alpha$ value for different sources.

In order to generalize spatial and temporal variability of $\alpha$, the additional calculations were performed. The analysis of $\mathrm{BC}$ and $\mathrm{OC}$ concentrations in Preila during both periods and in Rūgšteliškis during the cold period showed no significant influence of local sources. This leads to the assumption that averaged value of parameter $\alpha=80^{\circ}$ shows the influence of air mass long-range transport (Figure 5). Thus, this 
value of $\alpha$ was chosen as the baseline. It should be noted that $\alpha=90^{\circ}$ resembles $\mathrm{BC}$ concentration equal to zero and it indicates that carbonaceous aerosol originate from exclusively biogenic sources. Additionally, $\alpha=0^{\circ}$ indicate exclusively anthropogenic sources of carbonaceous aerosol.

The rural environment was clearly distinguished because it is mainly influenced by the biogenic emissions and long-range transport without local anthropogenic sources. On the other hand, the value of parameter $\alpha$ is not equal to $90^{\circ}$. This leads to the conclusion that the alteration of parameter $\alpha$ value in rural environments during the warm period was determined by biogenic sources, which increased the value of parameter $\alpha$ by $4^{\circ}$ in addition to long-range transport value.

Local traffic is one of the most important parameters influencing the $\mathrm{BC}$ concentration in urban environments [16]. The decrease of the $\mathrm{OC} / \mathrm{BC}$ ratio in urban environments during the warm period is a consequence of the vehicle traffic activity and other anthropogenic sources. For this reason, the highest $\alpha$ value alterations from the baseline were observed in Vilnius during the warm period. Low values of $\mathrm{OC} / \mathrm{BC}$ ratio are systematically associated with highest $\mathrm{BC}$ concentration [35]. During the cold period, $\mathrm{BC}$ and $\mathrm{OC}$ concentrations were affected by several local sources (vehicle traffic, domestic heating, industrial activities and other). The aerosols generated by domestic biomass burning consist mainly of OC, and smaller amounts of BC [36]. Thus, domestic heating increased both OC and BC concentrations, even though the strong influence of domestic heating in Vilnius during the cold period leads to higher $\mathrm{OC} / \mathrm{BC}$ ratios than in the warm period.

\section{Conclusions}

The $\mathrm{OC}$ and $\mathrm{BC}$ concentrations were determined for urban, rural and costal/marine environments during the warm and cold periods. The highest hourly $\mathrm{BC}$ aerosol mass concentration in urban background environments reached $17.23 \mu \mathrm{g} \cdot \mathrm{m}^{-3}$ during the cold period, while the mean $\mathrm{BC}$ concentration was found to be $2.34 \mu \mathrm{g} \cdot \mathrm{m}^{-3}$, which is about a factor of three higher than mean values in coastal/marine and rural sites $\left(0.84\right.$ and $0.77 \mu \mathrm{g} \cdot \mathrm{m}^{-3}$, respectively). It was estimated that the mean OC concentrations have distinct seasonal variations with the highest values observed $\left(8.60 \pm 7.04 \mu \mathrm{g} \cdot \mathrm{m}^{-3}\right)$ in urban backgrounds and lowest mean concentration $\left(3.01 \pm 2.56 \mu \mathrm{g} \cdot \mathrm{m}^{-3}\right)$ in coastal $/$ marine environment in the cold period. The minimum OC concentrations varied between $0.01 \mu \mathrm{g} \cdot \mathrm{m}^{-3}$ and $0.78 \mu \mathrm{g} \cdot \mathrm{m}^{-3}$, while the maximum values during the cold period $\left(75.44 \mu \mathrm{g} \cdot \mathrm{m}^{-3}\right)$ were more than four times higher of those in the warm period $\left(17.78 \mu \mathrm{g} \cdot \mathrm{m}^{-3}\right)$ in urban background environments. In contrast, the mean OC values measured during the warm period in coastal $/$ marine $\left(4.11 \mu \mathrm{g} \cdot \mathrm{m}^{-3}\right)$ and rural $\left(4.56 \mu \mathrm{g} \cdot \mathrm{m}^{-3}\right)$ environments was higher compared to the cold period (3.01 and $3.45 \mu \mathrm{g} \cdot \mathrm{m}^{-3}$, respectively). Strong influence of local sources of $\mathrm{BC}$ in urban environments and long-range transport in rural environments was observed. The carbonaceous aerosol shows a relative enrichment in $\mathrm{OC}$ during the warm period in coastal/marine and rural sites $\left(\alpha=84^{\circ}-85^{\circ}\right)$. The high values of $\mathrm{OC} / \mathrm{BC}$ ratio in forested (rural) areas suggest that $\mathrm{OC}$ emissions could be derived from biogenic sources. The decrease of the $\mathrm{OC} / \mathrm{BC}$ ratio in urban environment during the warm period was caused by the vehicle traffic activity and other anthropogenic sources.

\section{Acknowledgments}

This work was supported by the Lithuanian-Swiss Cooperation Programme "Research and Development" project AEROLIT (No. CH-3-ŠMM-01/08). 


\section{Author Contributions}

Julija Pauraite and Genrik Mordas conceived of and designed the experimental campaign, dataset analysis, and drafting of the manuscript; Vidmantas Ulevicius supervised the research topic; Steigvilè Byčenkienè wrote the paper.

\section{Conflicts of Interest}

The authors declare no conflict of interest.

\section{References}

1. Jimenez, J.L.; Canagaratna, M.R.; Donahue, N.M.; Prevot, A.S.H.; Zhang, Q.; Kroll, J.H.; DeCarlo, P.F.; Allan, J.D.; Coe, H.; Ng, N.L.; et al. Evolution of organic aerosols in the atmosphere. Science 2009, 326, 1525-1529.

2. Satsangi, A.; Pachauri, T.; Singla, V.; Lakhani, A.; Kumari, K.M. Organic and elemental carbon aerosols at a suburban site. Atmos. Res. 2012, 113, 13-21.

3. Pio, C.; Cerqueira, M.; Harrison, R.M.; Nunes, T.; Mirante, F.; Alves, C.; Oliveira, C.; Sanchez de la Campa, A.; Artíñano, B.; Matos, M. OC/EC ratio observations in Europe: Re-thinking the approach for apportionment between primary and secondary organic carbon. Atmos. Environ. 2011, 45, 6121-6132.

4. Calvo, A.I.; Alves, C.; Castro, A.; Pont, V.; Vicente, A.M.; Fraile, R. Research on aerosol sources and chemical composition: Past, current and emerging issues. Atmos. Res. 2013, 120, 1-28.

5. Viana, M.; Maenhaut, W.; ten Brink, H.M.; Chi, X.; Wijers, E.; Querol, X.; Alastuey, A.; Mikuška, P.; Večeřa, Z. Comparative analysis of organic and elemental carbon concentrations in carbonaceous aerosols in three European cities. Atmos. Environ. 2007, 41, 5972-5983.

6. Kumagai, K.; Iijima, A.; Tago, H.; Tomioka, A.; Kozawa, K.; Sakamoto, K. Seasonal characteristics of water-soluble organic carbon in atmospheric particles in the inland Kanto plain, Japan. Atmos. Environ. 2009, 43, 3345-3351.

7. Salako, G.O.; Hopke, P.K.; Cohen, D.D.; Begum, B.A.; Biswas, S.K.; Pandit, G.G.; Chung, Y.-S.; Rahman, S.A.; Hamzah, M.S.; Davy, P.K.; et al. Exploring the variation between EC and BC in a variety of locations. Aerosol Air Qual. Res. 2012, 12, 1-7.

8. Seinfeld, J.H.; Pandis, S.N. Atmospheric Chemistry and Physics: from Air Pollution to Climate Change. John Wiley \& Sons: New York, USA; pp. 1326.

9. Cyrys, J.; Heinrich, J.; Hoek, G.; Meliefste, K.; Lewne, M.; Gehring, U.; Bellander, T.; Fischer, P.; Van Vliet, P.; Brauer, M.; et al. Comparison between Different Traffic-related Particle Indicators: Elemental. Carbon (EC), PM2.5 Mass, and Absorbance. J. Exposure Anal. Environ. Epidemiol. 2003, 13, 134-143.

10. Ozdemir, H.; Pozzoli, L.; Kindap, T.; Demir, G.; Mertoglu, B.; Mihalopoulos, N.; Theodosi, C.; Kanakidou, M.; Im, U.; Unal, A. Spatial and temporal analysis of black carbon aerosols in Istanbul megacity. Sci. Total Environ. 2014, 473, 451-458. 
11. Schleicher, N.; Norra, S.; Fricker, M.; Kaminski, U.; Chen, Y.; Chai, F.; Wang, S.; Yu, Y.; Cen, K. Spatio-temporal variations of black carbon concentrations in the Megacity Beijing. Environ. Pollut. 2013, 182, 392-401.

12. Dumka, U.C.; Manchanda, R.K.; Sinha, P.R.; Sreenivasan, S.; Moorthy, K.K.; Babu, S.S. Temporal variability and radiative impact of black carbon aerosol over tropical urban station Hyderabad. J. Atmos. Sol. Terr. Phy. 2013, 105, 81-90.

13. Hyvärinen, A.P.; Kolmonen, P.; Kerminen, V.M.; Virkkula, A.; Leskinen, A.; Komppula, M.; Hatakka, J.; Burkhart, J.; Stohl, A.; Aalto, P.; et al. Aerosol black carbon at five background measurement sites over Finland, a gateway to the Arctic. Atmos. Environ. 2011, 45, 4042-4050.

14. Saha, A.; Despiau, S. Seasonal and diurnal variations of black carbon aerosols over a Mediterranean coastal zone. Atmos. Res. 2009, 92, 27-41.

15. Clarke, A.D.; Shinozuka, Y.; Kapustin, V.N.; Howell, S.; Huebert, B.; Doherty, S.; Weber, R. et al. Size distributions and mixtures of dust and black carbon aerosol in Asian outflow: Physiochemistry and optical properties. J. Geophys. Res. 2004, 109, D15S09.

16. Kondo, Y.; Matsui, H.; Moteki, N.; Sahu, L.; Takegawa, N.; Kajino, M.; Brune, W.H. Emissions of black carbon, organic, and inorganic aerosols from biomass burning in North America and Asia in 2008. J. Geophys. Res. 2011, 116, D08204.

17. Ning, Z.; Chan, K.L.; Wong, K.C.; Westerdahl, D.; Močnik, G.; Zhou, J.H.; Cheung, C.S. Black carbon mass size distributions of diesel exhaust and urban aerosols measured using differential mobility analyzer in tandem with Aethalometer, Atmos. Environ. 2013, 80, 31-40.

18. Byčenkienè, S.; Ulevicius, V.; Kecorius, S. Characteristics of black carbon aerosol mass concentration over the East Baltic region from two-year measurements. J. Environ. Monit. 2011, 13, 1027-1038.

19. Cape, J.N.; Coyle, M.; Dumitrean, P. The atmospheric lifetime of black carbon. Atmos. Environ. 2012, 59, 256-263.

20. Aruna, K.; Lakshmi Kumar, T.V.; Narayana Rao, D.; Krishna Murthy, B.V.; Suresh Babu, S.; Krishna Moorthy, K. Black carbon aerosols in a tropical semi-urban coastal environment: Effects of boundary layer dynamics and long range transport. J. Atmos. Sol. Terr. Phy. 2013, 104, 116-125.

21. Grivas, G.; Cheristanidis, S.; Chaloulakou, A. Elemental and organic carbon in the urban environment of Athens. Seasonal and diurnal variations and estimates of secondary organic carbon. Sci. Total Environ. 2012, 414, 535-545.

22. Wang, F.; Guo, Z.; Lin, T.; Hu, L.; Chen, Y.; Zhu, Y. Characterization of carbonaceous aerosols over the East China Sea: The impact of the East Asian continental outflow. Atmos. Environ. 2015, $110,163-173$.

23. Guzman-Morales, J.; Frossard, A.A.; Corrigan, A.L.; Russell, L.M.; Liu, S.; Takahama, S.; Taylor, J.W.; Allan, J.; Coe, H.; Zhao, Y.; et al. Estimated contributions of primary and secondary organic aerosol from fossil fuel combustion during the Cal-Nex and Cal-Mex campaigns. Atmos. Environ. 2014, 88, 330-340.

24. Huang, X.F.; Gao, R.S.; Schwarz, J.P.; He, L.Y.; Fahey, D.W.; Watts, L.A.; McComiskey, A.; Cooper, O.R.; Sun, T.L.; Zeng, L.W.; et al. Black Carbon measurements in the Pearl River Delta Region of China. J. Geophys. Res. Atmos. 2011, 116, D12208.

25. Rattigan, O.V.; Civerolo, K.; Doraiswamy, P.; Felton, H.D.; Hopke, P.K. Long term black carbon measurements at two urban locations in New York. Aerosol Air Qual. Res. 2013, 13, 1181-1196. 
26. Byčenkienè, S.; Plauškaitè, K.; Dudoitis, V.; Ulevicius, V. Urban background levels of particle number concentration and sources in Vilnius, Lithuania. Atmos. Res. 2014, 143, 279-292.

27. Ulevicius, V.; Byčenkienė, S.; Remeikis, V.; Garbaras, A.; Kecorius, S.; Andriejauskienė, J.; Jasinevičienè, D.; Mocnik, G. Characterization of pollution events in the East Baltic region affected by regional biomass fire emissions. Atmos. Res. 2010, 98, 190-200.

28. Middlebrook, A.M.; Bahreini, R.; Jimenez, J.L.; Canagaratna, M.R. Evaluation of Composition-Dependent Collection Efficiencies for the Aerodyne Aerosol Mass Spectrometer using Field Data. Aerosol Sci. Techl. 2012, 46, 258-271.

29. Collaud Coen, M.; Weingartner, E.; Apituley, A.; Ceburnis, D.; Fierz-Schmidhauser, R.; Flentje, H.; Henzing, J.S.; Jennings, S.G.; Moerman, M.; Petzold, A.; et al. Minimizing light absorption measurement artifacts of the Aethalometer: evaluation of five correction algorithms. Atmos. Meas. Tech. 2010, 3, 457-474.

30. Rozwadowska, A.; Zielinski, T.; Petelski, T.; Sobolewski, P. Cluster analysis of the impact of air back-trajectories on aerosol optical properties at Hornsund, Spitsbergen. Atmos. Chem. Phys. 2010, 10, 877-893.

31. Draxler, R.R.; Rolph, G.D. HYSPLIT (HYbrid Single-Particle Lagrangian Integrated Trajectory) Model access via NOAA ARL READY Website 2015. Available online: http://ready.arl.noaa.gov/HYSPLIT.php (accessed on 5 August 2015).

32. Aurela, M.; Saarikoski, S.; Timonen, H.; Aalto, P.; Keronen, P.; Saarnio, K.; Teinilä, K.; Kulmala, M.; Hillamo, R. Carbonaceous aerosol at a forested and an urban background sites in Southern Finland. Atmos. Environ. 2011, 45, 1394-1401.

33. Zappoli, S.; Andracchio, A.; Fuzzi, S.; Facchini, M.C.; Gelencsér, A.; Kiss, G.; Krivácsy, Z.; Molnár, Á.; Mészáros, E.; Hansson, H.C.; et al. Inorganic, organic and macromolecular components of fine aerosol in different areas of Europe in relation to their water solubility. Atmos. Environ. 1999, 33, 2722-2743.

34. Castro, L.M.; Pio, C.A.; Harrison, R.M.; Smith, D.J.T. Carbonaceous aerosol in urban and rural European atmospheres: Estimation of secondary organic carbon concentrations. Atmos. Environ. 1999, 33, 2771-2781.

35. Asmi, A.; Wiedensohler, A.; Laj, P.; Fjaeraa, A.M.; Sellegri, K.; Birmili, W.; Weingartner, E.; Baltensperger, U.; Zdimal, V.; Zikova, N.; et al. Number size distributions and seasonality of submicron particles in Europe 2008-2009. Atmos. Chem. Phys. 2011, 11, 5505-5538.

36. Novakov, T.; Menon, S.; Kirchstetter, T.W.; Koch, D.; Hansen, J.E. Aerosol organic carbon to black carbon ratios: Analysis of published data and implications for climate forcing. J. Geophys. Res. 2005, 110, D21205.

(C) 2015 by the authors; licensee MDPI, Basel, Switzerland. This article is an open access article distributed under the terms and conditions of the Creative Commons Attribution license (http://creativecommons.org/licenses/by/4.0/). 